\title{
A MULTI-COUNTRY STUDY OF FACTORS AFFECTING CREDIT RATINGS REVISIONS
}

\author{
Angeline Siew-Huan Ng* \\ Universiti Putra Malaysia \\ Mohamed Ariff Syed Mohamed \\ Sunway University Malaysia
}

\begin{abstract}
This paper reveals findings from extending corporate credit rating studies towards (i) new ratings, affirmation, confirmation, watchlists, and withdrawal, which together represent five out of eight rating types yet to be studied rigorously (there are several papers on upgrades and downgrades); and (ii) identifying key firm-specific factors affecting stock prices around the rating revisions in markets not yet studied. The firmspecific factor effects are measured using the Ordered Probit methodology. Results show that investment and speculation grade issues have the most pronounced effects on price changes. Further findings are: interest-coverage, profitability and leverage ratios, all of which stand out as the most relevant firm-specific factors correlated with stock price changes. An interesting new finding is the discovery of corruption perception scores as a new measure is significantly influencing affirmation, confirmation and downgrade ratings. These new findings are likely to be of interest to investors, corporations wanting to know rating change effects and the external regulators concerned with financial weaknesses/strengths of listed firms facing rating changes.
\end{abstract}

Keywords: Credit rating, New, Affirmation, Confirmation, Withdrawal Ratings, Ordered Probit Model

Received: 5 September 2019

Accepted: 14 September 2020

\section{INTRODUCTION}

This paper has two aims: (i) report new findings on the less studied rating effects from five types of credit ratings yet studied and (ii) identify key firm-specific/general factors associated with credit rating changes. The literatures on credit ratings is mostly about the effects on stock prices from credit upgrades and downgrades in few major world economies such as the United States (U.S.) where data are more readily available due to oversight rules of mature rating markets. There is also an apparent lack of attention on other type of ratings. Whereas, this paper is on four selected developed economies in the Asia-Pacific region: Australia, Hong Kong, South Korea and Japan. This study extends the literature to other less-studied credit rating types and discovers key factors associated with stock-price changes in a multi-market setting. Not only are the results

\footnotetext{
* Corresponding author: Faculty of Economics and Management, University Putra Malaysia, Serdang, 43400 Seri Kembangan, Selangor; Email: angeline2013@gmail.com; Phone: +60122992769.
} 
new for the four major Asia Pacific economies, the extension of the study towards item (ii) makes the study offer significant new direction.

Credit rating agencies (CRAs) are independent agents with a critical say as opinion on corporations' abilities to service debts. CRAs play significant and increasingly (allegedly) ominous role in making a verdict based on their private-assessment of a firm's creditworthiness by rating revisions. The credit rating literature is not extensive on the important factors influencing credit rating correlated with stock price changes at the time of rating analysed by different types of ratings. Therefore, this paper will help provide some answers to issuers and investors to make more effective investment decisions on several rating revisions.

CRAs are criticized widely for not warning the public adequately on impending bankruptcies; for amplify ratings due to conflicts of interest in competition for more business; and for their role in the 2008-9 sub-prime mortgage crisis. Gigantic firm such as Lehman Brothers in 2008 were still rated investment grades by Moody's Investors Service (Moody’s) and S\&P Global Ratings (S\&P) near to their bankruptcy filing! Subjective judgments often play vital role in the rating process, it is alleged. Rating inflation is acute if the brokerage firms assist the same firms that solicit funding issues with related parties since the related brokerage firms have high inclination to amplify their stock recommendations to secure more business (Chan, Karceski, \& Lakonishok, 2007; Lim, 2001). That is a telling criticism at the micro-level of the rating phenomenon. Notwithstanding shortfalls from critiques, CRAs are still highly sought after for their certification services to induce investors to invest thus they play a pivotal role in information signal to investors and policy makers.

When a country/firm wants to access a capital market for funds, the governments/managers seek credit ratings from the CRAs (Figure 1). The certification impacts are enormous to governments and firms such as higher foreign direct investment flow (Cai, Gan, \& Kim. 2018; Ismailescu \& Kazemi, 2010), ability to raise funds at cheaper cost (Agarwal, 2013; Modina, 2015), lower merger and acquisition fees for rated targets compared to non-rated firms (Karampatsas, Petimezas, \& Travlos, 2014) and significantly increasing incumbent election prospects (Cunha, Ferreira, \& Silva, 2016) in governments.

Figure 1: Raising Capital through Rated Securities

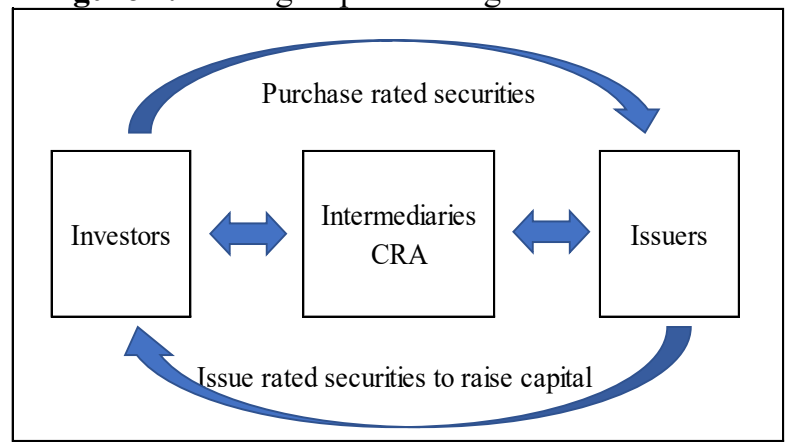


The life cycle of a rated firm commences with an 'initial' (new) rating, and this may frequently follow with a rating 'affirmation' with no changes. Alternately, CRAs may place the firm under 'Watchlist' status upon receiving news, normally concluded within 90 days by a subsequent announcement whether the firm will be downgraded or upgraded. Firms with deteriorating finances and high-level debts are potentially downgrade by CRAs, indicating their inabilities to service debt. On the other hand, a 'confirmation' rating takes place when removed from Watchlist status (Moody's, 2009) with no rating revision. The rating life cycle ends when the rating of a firm is 'withdrawn' from the market for several reasons. Ratings can be withdrawn when issuer consolidates the holding or family control normally wanting to possess better rating. Ratings withdrawal also occurs due to merger and acquisition, insolvency, insufficient information, reorganization and bankruptcy. Once the rating is withdrawn, the issuer will no longer be rated by the CRAs.

\section{Research Questions}

CRA's role is not limited to initial information dissemination but also other rating changes. Past research focus has always been on rating upgrades and downgrades as noted. This study is motivated to address the lack of scrutiny on firms by studying possible factors influencing creditrating changes/revisions around disclosures times by individual rating type: new, affirmations, confirmations and withdrawal ratings less studied, using Ordered Probit approach. (There are eight rating revisions in total in this study.) A rating withdrawal could be detrimental if the issuer is forced to settle its debt immediately upon a loss of rating. Therefore, do these credit rating disclosures yield valuable information to the investors?

This paper also extends the work of Gray, Mirkovic, and Ragunatha (2006) in three directions. First, we select four developed countries instead of focusing only on Australia, to obtain a wider perspective. Second interesting feature is we extend the ratings approach up to five values using Ordered Probit method to discriminate effectively between the investment and speculation-rated firms. In contrast, Gray et al., (2006) used three types and limited the search to investment grades firms only. Third, we introduce two interesting variables; (i) corruption perception index (CPI), an index published annually by Transparency International since 1995; and (ii) re-investment variable to distinguish the investment issues from the speculation-rated issues for all rating changes.

The paper is first organized with an introduction. This follows a literature review in Section 2 and Section 3 describes the data and methodology. We present the findings and comment our thoughts as our interpretations of major findings reported in Section 4. Lastly, Section 5 concludes the paper.

\section{RELEVANT LITERATURE REVIEW}

This study is in line with the emergent resurgence of interest concerning the effects of CRA's rating actions on firms' behavior compared to the vast literature on credit ratings. We discuss only the articles closely related to our work. Modigliani and Miller (1958) assume market information is symmetric in a perfect market when firms and investors possess the same information. However, this assumption is not realistic since managers possess more information 
than investors (Myers \& Majluf, 1984). Information asymmetry also known as information failure occurs when one party possesses greater information than another. Hence, one of the market conflicts is information asymmetry between managers and investors about the firm's value, which the CRAs address.

Empirical studies by Barron, Clare, and Thomas (1997), Sufi (2009), Becker and Milbourn (2011), Fulghieri, Strobl, and Xia. (2014), Safari and Ariff (2015), and Ng and Ariff (2019) show significant contributions by CRAs influencing the markets. Information asymmetry is reduced when firms use the assessment and monitoring expertise of CRAs (Boot, Milbourn, \& Schmeits, 2006; He, Wang, \& Wei, 2011; Livingston \& Zhou, 2016). In a survey conducted using 392 chief financial officers, Graham and Harvey (2001) find 57\% of respondents indicate a good credit rating is the second most important factor in determining debt policy while financial flexibility is the first factor.

There is a paucity of studies of the impact on stock returns from other than studies of rating upgrades, suggesting the absence of information content (Holthausen \& Leftwich, 1986; Goh \& Ederington, 1993; Barron et al., 1997) on other types. However for firms with rating downgrades by empirical literature of Holthausen and Leftwich (1986) and Jorion and Zhang (2007) find significant effects on daily stock returns. Issuers have little incentive to leak negative news prior to downgrades. For CreditWatch ratings, where a review is possible for a further upgrade or downgrade or confirmation with no rating change, Matolcsy and Lianto (1995) and Elayan, Hsu, and Meyer (2003) report significant impact from these on stock returns. Boot et al., (2006) note that CreditWatch is a form of monitoring devise and the effectiveness of rating changes are influenced by the information collection in the evaluation procedures, hence, this will possibly affect the information content of rating changes. On the other hand, new entrants and firms with rating affirmations are rarely studied; $\mathrm{Ng}$ and Ariff (2019) show that these ratings have significant impact also on stock returns.

In response to new information provided by CRAs, investors benefit by separating 'risky/speculative' investments and high-quality investments. Ryan, Villupuram, and Zygo (2017) and Dichev and Piotroski (2001) analysed the speculative and investment-grade firms concentrating on two classification of credit risk (downgrades and upgrades) and find significant impact from rating downgrades. In the same spirit, Tang (2009) shows firms with favourable ratings enjoy better access to capital markets (an "A1" rating (investment-grade) is better than "B1" (speculative-grade)) help raise more funds (Sufi, 2009). Low-credit rated entities pay higher interest rates than those with better credit scores. Therefore, the assessment provided by CRAs stimulate borrowers to pursue sounder financial and economic policies to access international capital markets (Agnello, Castro, \& Sousa, 2018). Firms that obtain credit ratings from CRAs increased their borrowings since the managers are able to raise more funds in syndicated debt financing (Sufi, 2009). Thus, these rated firms suffer less from underinvestment due to capital constraints (Harford \& Uysal, 2014).

Credit ratings and corporate defaults are closely related. Lower rated firms are more likely to default than those with higher ratings. Using financial ratios in a default prediction model is often analysed in rating prediction and the estimation is centered around the seminal work of Altman (1968) and later. Managers can initiate remedial actions to circumvent deterioration and investors can adjust their investment strategies to reduce anticipated losses. Therefore, a firm's default risk 
is a forward-looking measure of the firm's probability of default. Shen, Huang, and Hasan (2012) and Vives (2006) point to the effect of financial ratios on banks' credit ratings as being significant as measured by the level of information asymmetries.

CRAs are concerned with corporate governance issue because weak governance impairs a firm's financial position and may lead to investors vulnerable to losses. Corruption is part of corporate governance measure and countries with higher corruption index show less capability to service debt obligations, and garner lower credit ratings (Erdem \& Varli, 2014; Jain, Kuvvet \& Pagano, 2017; Mellios \& Paget-Blanc, 2006). Jain et al., (2017) argue that countries with high corruption levels will lead to more asymmetric information, thus to investor uncertainty, hence lead to negative impact on foreign equity investment. From an economic standpoint, the operating and financing cost will increase due to corruption.

Dichev and Piotroski (2001), May (2010) and Ryan et al., (2017) studied the credit rating reaction effects of speculative versus investment grade firms using downgrades and upgrades. Firms are more restricted in their access to credit, because of information asymmetry problems in the relationship between management versus investors. May (2010) shows that the reactions to an upgrade are strong if the firm upgrades from speculative to investment grade. While most firms default within the range from one to five years (median) from the original rating have speculative-grade ratings, by comparison, only eight firms with bonds initially rated as AAA defaulted over the 1981-2017 period with 18.5 median years from the original rating: this is a definitive study using 2,672 rated global corporates (Standard \& Poor's 2017, p. 37). Akhigbe, Madura, and Whyte (1997) find that private information disclosed to markets through credit rating changes extends not only to rated firms but also to other firms operating in the same industry. Hence, the importance of studying the distinction between speculative and investment grades for study.

\section{DATA DESCRIPTION AND METHODOLOGY}

\subsection{Data Description}

Four developed countries are selected for study: Australia, Japan, Korea and Hong Kong (an economy not a country) within the Asia-Pacific region. The sample selection is over a 15-year period from 2004 to 2018, using the rating information from Moody's database to control diversity of ratings. The financial statements are obtained from Datastream, Yahoo Finance and Bloomberg. Corruption perception index data is obtained from the Transparency International Reports. There are 467 observations comprising firms with investment ratings (72\%) and speculative ratings (28\%) and we study the rating types seldom studied by others.

Australia is selected in this study as the country is amongst ones with the most developed capital markets in the world. Australia has been relatively immune to adverse macroeconomic shocks compared to the U.S. economy often susceptible to financial crises (Brown \& Davis, 2010). According to the World Investment Report 2017, Japan is a top prospective investment preference developed countries besides the U.S. This is also pointed to by Ismailescu and Kazemi (2010) that majority of countries look to the U.S. for investment while Asian nations turn to Japan for financing. Korea is selected due to the country's resiliency and improved monitoring 
systems following the stronger institutional developed following the 1997 Asian financial crisis, which in turn steered and increased the importance of credit rating in the country (Black \& Kim, 2012). Hong Kong's stock market is mature and highly liquid. The Hong Kong Stock Exchange was ranked fourth globally with funds raised of USD14.7 billion (KPMG, 2017) and the initial public offerings in Hong Kong were oversubscribed in 2017 reflecting strong investor confidence in the Hong Kong economy.

\subsection{Rating Scale}

Table 1 is a summary of long-term rating symbols and interpretations for three major CRAs; Moody's, S\&P and Fitch Ratings (the 'Big Three'), all of which dominate 95\% of the global rating industry market. Moody's and S\&P each hold 40\% and Fitch about 15\% (Christopher, 2012). The rating scales are classified into two groups; investment and speculation grades.

Table 1: Rating Scale and Interpretation

\begin{tabular}{|c|c|c|c|c|}
\hline $\begin{array}{l}\text { Moody's* } \\
\text { Panel A: }\end{array}$ & \multicolumn{2}{|c|}{ Investment Grade } & \multicolumn{2}{|r|}{ Remarks } \\
\hline Aaa & AAA & AAA & & $\begin{array}{l}\text { Highest credit quality. The firm has extremely strong } \\
\text { credit standing. }\end{array}$ \\
\hline Aa1 & $\mathrm{AA}+$ & $\mathrm{AA}+$ & ] & \\
\hline $\mathrm{Aa} 2$ & AA & AA & ] & Very strong capacity to meet financial commitments. \\
\hline Aa3 & AA- & AA- & ] & \\
\hline A1 & $\mathrm{A}+$ & $\mathrm{A}+$ & ] & $\begin{array}{l}\text { High credit quality. Capacity to meet financial } \\
\text { commitments is still strong. }\end{array}$ \\
\hline A2 & A & A & ] & \\
\hline A3 & A- & A- & ] & \\
\hline Baal & $\mathrm{BBB}+$ & $\mathrm{BBB}+$ & ] & Adequate capacity to meet financial commitment. \\
\hline Baa2 & $\mathrm{BBB}$ & $\mathrm{BBB}$ & ] & \\
\hline $\mathrm{Baa} 3$ & BBB- & BBB- & ] & \\
\hline \multicolumn{5}{|c|}{ Panel B: Speculative Grade } \\
\hline Bal & $\mathrm{BB}+$ & $\mathrm{BB}+$ & ] & Indicate vulnerability to default risk. \\
\hline $\mathrm{Ba} 2$ & BB & BB & ] & \\
\hline $\mathrm{Ba} 3$ & BB- & BB- & ] & \\
\hline B1 & $\mathrm{B}+$ & $\mathrm{B}+$ & ] & $\begin{array}{l}\text { Capacity for continued payment is vulnerable due to } \\
\text { deterioration in business and economic }\end{array}$ \\
\hline B2 & $\mathrm{B}$ & $\mathrm{B}$ & ] & environment. \\
\hline B3 & B- & B- & ] & \\
\hline Caal & $\mathrm{CCC}+$ & $\mathrm{CCC}$ & & Default is highly likelihood. \\
\hline $\mathrm{Caa} 2$ & $\mathrm{D}$ & $\mathrm{D}$ & & Payments are in default. \\
\hline Caa3 & $\mathrm{D}$ & $\mathrm{D}$ & ] & In bankruptcy or default shortcoming. \\
\hline $\mathrm{Ca} / \mathrm{C}$ & $\mathrm{D}$ & $\mathrm{D}$ & 1 & \\
\hline
\end{tabular}

Sources: *Moody's Rating Symbols and Definitions (2009); **Standard \& Poor's Ratings Definitions (2012); \#Fitch Ratings - Definitions of Ratings (2014)

\subsection{Ordered Probit Methodology}


Credit ratings are discrete data that take a finite number ranging from Aaa to $\mathrm{D}$, rather than continuous values. Discrete data can take on only integer values whereas continuous data can take any value (Gray et al., 2006; Kaplan \& Urwitz, 1979). Kaplan and Urwitz (1979) document that using publicly available data can predicate to some level of accuracy by employing Ordered Probit methodology. Second, credit ratings have natural ordering/ranking. Aa1 is higher than Aa2, which in turn is higher than Bal and so forth. The Ordered Probit methodology is able to make differentiation using the integer values. This method is a well-accepted approach in credit rating literature, following Blume, Lim, and MacKinlay (1998); Bouzouita and Young (1998); Gray et al., (2006); and Ozturk, Namli, and Erdal (2016). The matrix data table consists of fiveprobability value (Table 2). The dependent variable is assigned the value of 1 if the firm is rated between Aaa to Aa3; 2 if firm is rated A1, A2, A3 and so forth. Probability value from 1 to 3 refers to firms in investment grades whilst speculation firms fall under the values of 4 and 5 .

Table 2: Matrix Table for Ordered Probit

\begin{tabular}{lllllc}
\hline \hline Probability Value & 1 & 2 & 3 & 4 & 5 \\
\hline \multirow{3}{*}{ Rating Announcement } & Aaa & A1 & Baa1, & Ba1, & B1 \\
& Aa1 & A2 & Baa2, & Ba2, & B2 \\
& Aa2 & A3 & Baa3 & Ba3 & B3 \\
& Aa3 & & & & C \\
\hline \hline
\end{tabular}

The ratings are coded in ordinal values as below;

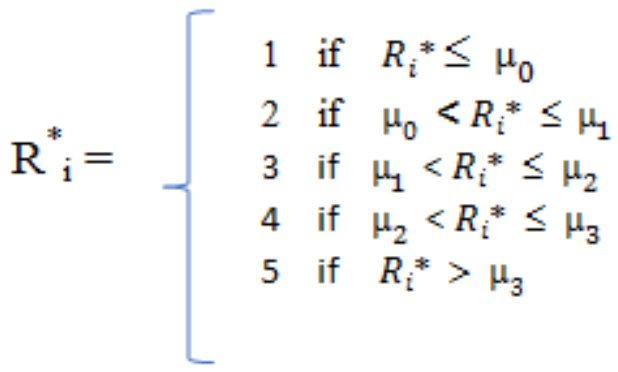

The explanatory variable is described in Eq. (1) below;

$$
\mathrm{R}^{*}{ }_{\mathrm{i}}=\mathrm{X}_{\mathrm{i}} \beta+\varepsilon_{\mathrm{i}}
$$

Where $\mathrm{R}^{*}$ is an unobserved continuous variable of the CRA's assessment of the issuer; $\mathrm{R}_{\mathrm{i}}$ is the observed rating category assigned to issuer $\mathrm{i}$ (the observed rating categories are assumed to represent ordered partitionings of the above continuous scale); $\mathrm{Xi}$ is a vector of explanatory variables for issuer $\mathrm{i} ; \beta$ is a vector of coefficients; $\varepsilon \mathrm{i}$ is a standard normal random error with mean zero and variance and $\mu_{\mathrm{i}}$ is threshold parameters. The final output of the Ordered Probit analysis is therefore a guideline to reflect the magnitude effect of each explanatory variable on the rating changes. This specification allows the intercept to vary over time while constraining the slope 
coefficients $\beta$ to be constant over time. Changes in the intercept over time can be viewed as a measure of change used in assigning ratings.

The equation for Ordered Probit modeling is as below:

$$
\mathrm{R}_{\mathrm{i}, \mathrm{t}}=\alpha+\beta_{1} \mathrm{X}_{1 \mathrm{it}}+\beta_{2} \mathrm{X}_{2 \mathrm{it}}+\beta_{3} \mathrm{X}_{3 \mathrm{it}}+\beta_{4} \mathrm{X}_{4 \mathrm{it}}+\ldots .+\beta_{\mathrm{t}} \mathrm{X}_{\mathrm{it}}+\varepsilon_{\mathrm{it}}
$$

Where;

$\begin{array}{lll}\mathrm{R}_{\mathrm{i}, \mathrm{t}} & : & \text { dependent variable taking an assigned value } \\ \alpha & : & \text { the intercept } \\ \beta_{1} \ldots \beta_{\mathrm{t}}: & \text { coefficients of the independent variables } \\ \mathrm{X}_{1} \ldots \mathrm{X}_{\mathrm{t}} & : & \text { independent variables } \\ \varepsilon & : & \text { error term }\end{array}$

\subsection{Transformation of Financial Ratios}

Financial data collected are transformed to ratios and subsequently to logarithm, as opposed to using absolute values, to correct deviations from normality and uneven variance (heteroskedasticity), as well as to reduce fat tails. A fat-tailed distribution also known as heavytailed statistical distribution describes the probability of certain events. Tail risk is a form of portfolio risk arises when the possibility that an investment will move more than three standard deviations from the mean is greater than what is shown by a normal distribution. Log transformation is applied to the variables to improve normality and reduce heteroskedasticity. The $\log$ transformations also reduce skewness in the distributions into one that is more approximately normal.

\subsection{Reasons for Selection Specific Ratios}

Models should be simple, aid in rational decision making and few parameters are preferable to many, according to the principle of parsimony (Bouzouita \& Young, 1998). According to S\&P (2006), there are no fixed rules in assigning a credit rating as subjectivity is at the heart of every rating. Moody's and S\&P use key financial ratios on profitability, interest coverage and leverage in their analysis of credit worthiness. This study employed selected ratios including profitability, interest coverage and leverage and included corruption perception index as a corporate governance measure; these are introduced as control variables (Table 3).

Table 3: Tested Variables

\begin{tabular}{llll}
\hline \hline No. & Coverage & \multicolumn{1}{c}{ Independent Variables } & Acronym \\
\hline 1 & Profitability & $\begin{array}{l}\text { Return on capital employed } \\
\text { Expressed in ratio of earnings before interest and tax / total capital }\end{array}$ & ROCE \\
2 & Profitability & $\begin{array}{l}\text { Return on assets } \\
\text { Expressed in ratio of net income / total asset }\end{array}$ \\
3 & Profitability & $\begin{array}{l}\text { Operating profit margin measures the percentage of a firm } \\
\text { produces from operations before deducting interest charges and } \\
\text { taxes. }\end{array}$ & OPMARGIN \\
4 & Interest & $\begin{array}{l}\text { EBITDA interest coverage } \\
\text { Expressed in ratio of EBITDA to total interest expense. }\end{array}$ & EBITDAInt \\
\end{tabular}




\begin{tabular}{|c|c|c|c|}
\hline No. & Coverage & $\begin{array}{ll}\text { Independent Variables } \\
\end{array}$ & Acronym \\
\hline & coverage & $\begin{array}{l}\text { (EBITDA is earnings before interest, tax, depreciation and } \\
\text { amortization) }\end{array}$ & \\
\hline 5 & Leverage & Long term debt / total capital & LTDCAP \\
\hline 6 & Leverage & Total debt / total assets & TDTA \\
\hline 7 & $\begin{array}{l}\text { Corruption } \\
\text { Perception } \\
\text { Index }\end{array}$ & $\begin{array}{l}\text { The CPI measures the perceived corruption level of the } \\
\text { country. Corruption threatens the sustainability of } \\
\text { a country's economic. }\end{array}$ & CPI \\
\hline 8 & $\begin{array}{l}\text { Re- } \\
\text { Investment }\end{array}$ & $\begin{array}{l}\text { This is a dummy variable that takes value } 0 \text { for investment } \\
\text { grade firms; and } 1 \text { for speculation grade firms. }\end{array}$ & DGRADE \\
\hline
\end{tabular}

\section{Profitability}

The accounting variables to be examined are (i) operating profit margin (OPMARGIN); (ii) return on capital employed (ROCE); and (iii) ROA; following Adams, Burton, and Hardwick (2003); Bouzouita and Young (1998), Gray et al., (2006); and Jiraporn, Jiraporn, Boeprasert, and Chang (2014) finding profitability variables statistically significant. Profitability reflects the firm's ability to maintain strong operation and adequate pricing. Operating profit margin measures the amount of income earned before paying off interest and tax expenses while ROCE and ROA assess the efficiency of how a firm utilizes equity and assets to generate earnings. ROCE measures a firm's profitability, which is capital-use efficiency. The ROCE ratio is considered an important profitability ratio, often used by investors to select well-funded investments. ROA is measured by net income over total assets, as the firm's ability to generate profit as a percentage of its total assets. The coefficients of the variables are expected to be positive.

\section{Interest coverage}

Interest coverage measures a firm's ability to generate sufficient cash to pay interest expenses on outstanding debts (Bouzouita \& Young, 1998; Doumpos, Niklis, Zopounidis \& Andriosopoulos, 2015). It is represented by EBITDA (earnings before interest, tax, depreciation and amortization) over total interest expense. The interest coverage ratio (EBITDAInt) is expected to have a positive effect because the higher the interest coverage ratio, the firm has greater ability to service interests.

\section{Leverage}

Long-term total debt to total capital (LTDTCAP), and total debt to total assets (TDTA) are proxies to the leverage analysis. Rating agencies place more weight on long-term debt relative to short-term debt (Gray et al., 2006). Leverage is tested as the proportion of a firm's assets financed through debt; Altman (1968); Bouzouita and Young, 1998; Jorion, Liu, and Shi (2005); and $\mathrm{Ng}$ and Ariff (2019). High level of debt increases a firm's default probabilities, hence it also increases insolvency. The coefficient of the variable is expected to be negative 


\section{Corruption Perception Index (CPI)}

The CPI measures perception of corrupt behavior of management. Due to the difficulty of measuring absolute levels of corruption, we use the data as in Corruption Perceptions Index (Corruption Perceptions Index, 2010). The higher the CPI scores the better is the investment environment using a scale from 0 (highly corrupted) to 100 (least corrupted). In this research, Australia has a CPI score of 77 compares to Afghanistan with a lower score of 15 according to CPI 2017 Report. Hong Kong and Japan have a CPI score of 77 and 73 respectively while South Korea has a score of 54 in the year 2017.

Corruption is increasingly argued to be a barrier to development and economic growth (Wilhelm, 2002). Podobnik, Shao, Njavro, Ivanov \& Stanley (2008) find there is a strong correlation between economic growth and corruption levels. They show that an increase of CPI by one unit leads to an increase of the annual GDP per capita by $1.7 \%$ on an average for all countries. Corruption also distorts a country's legal system, weakens institutions foundation and slower development of the nation. The nation and firms will have lesser resources to work with and resulting in the businesses not effectively operate.

\section{Re-investment}

The re-investment variable takes value 0 for investment grade firms; and 1 for speculative grade firms. It serves as a proxy variable for qualitative facts and isolating time effect in a regression model (Gujarati, 2003). The re-investment variable is influenced by quantitative factors, but also by qualitative factors such as the management team and board of directors. This variable is to control the number of rating changes. This distinction is critical because many large institutions and pension funds are mandated to invest in investment grade instruments only (White, 2002).

\section{FINDINGS AND DISCUSSIONS ON CREDIT REVISION IMPACT}

Table 4 shows results of the relationship between credit rating changes and selected independent variables. The Ordered Probit regression examines each individual rating change rather than all ratings together, to have better understanding on the independent variables significantly affect each rating. The variance inflation factors (VIF) for each credit rating variable is below 10 showing no multicollinearity among independent variables. Overall, the model is statistically significant as evidenced by the Wald Chi-squared value with a p-value of 0.0000 for each rating category. The results are analyzed according to the grouping of the financial ratios.

The re-investment variable distinguishes between investment and speculative grades yields, and this is an important result of this study. The coefficient for the re-investment ratings level is positive and highly significant at 0.01 level probability almost for all ratings. The standard deviation (measurement of dispersion) of the re-investment (DGRADE) generally is the smallest and nearer to the mean among all the variables in each category of ratings (Appendix 1). Our results are consistent with Becker and Milbourn (2011) and Ryan et al., (2017) document significant coefficient values of the investment grade thus suggesting that investment grade firms have lower probability of default than those rated as speculative. The speculative rated firms generally experience greater negative abnormal returns than investment rated firms, negative 
reaction to information asymmetry and have higher tendency to default. Hence, these four developed country behavior is similar to those reported in other studies. Remarkably, affirmation is highly significant and the watch upgrades rating have greater and significant impacts than the watch downgrades as measured by the coefficients size. This suggests that the watch upgrades and affirmation ratings offer more information, so offering greater assurance to investors. With favourable rating upgrades (includes watch upgrades) and no further downgrading (affirmation), investors will gain more confidence to invest in investment grade firms and may raise more capital for business expansion with expectation of lower borrowing cost.

The profitability ratios (represented by ROCE, ROA and operating profit margin) are statistically significant particularly for new and withdrawal ratings, followed by watch downgrade, watch upgrade and upgrades. The signs are positive except for one negative sign (ROCE) for rating withdrawal. There is a lack of studies on withdrawals so we are unable to compare. This suggests firms especially with speculative ratings are facing financial difficulties, hence are induced to withdraw from the rating market. Ratings withdrawal signals to investors a potential major change in the firm's performance. Firms and investors are concerned on the firm's ability to generate profits, which is pivotal for new entrants in the credit rating industry. Firms in watch downgrade, watch upgrade and just upgrades are no lesser of concern, as managers need to improve profitability as the first line of defence against losses and risk of downgrading by the CRAs.

Interest coverage is measured by earnings before interest, tax, depreciation and amortization (EBITDA) to interest expense, is significant impacting rating changes. These results are in line with what other researchers have reported; Doumpos et al., (2015), Gray et al., (2006), Amato and Furfine (2004). EBITDA interest coverage is statistically significant; new, affirmation, watch downgrade, and confirmation. These results indicate that rating agencies emphasize the importance of EBITDA as a stringent ratio after depreciation and amortization. It reflects a firm's true ability to service interest obligations from operational revenues. The sign for EBITDAInt is negative in our result. According to Gray et al., (2006) and Amato and Furfine (2004), interest coverage can be negative when earnings are negative. It is arguable that any increase (decrease) in operating incomes after depreciation should have positive (negative) effect for improving (decreasing) ratings. If the operating income is negative, a decline in interest expense will generally improve the net profit margin.

Next, long term debt to total capital (LTDCAP) and total debt to total assets (TDTA) are measures of leverage and statistically significant similar to previous studies by Amato and Furfine (2004), and Blume et al., (1998). The leverage ratios are significant to rating confirmation, withdrawal, affirmation and watch downgrade. The estimated coefficients are negative except for three positives exceptions for TDTA (rating affirmations, watch downgrades and withdrawal). This exception means that a firm with long-term debt leverage at any given level has more short-term debt in its capital structure while seeking better credit rating. If leverage taken at face value, this exception means that for a given level of long-term debt as leverage, a firm with more short-term debt in its capital structure will tend to receive a higher credit rating. Increases in leverage may increase the risk of insolvency, a result congruent to theory and empirics in the literature. 
An interesting observation is how corruption perception index (CPI) affects significantly three ratings; affirmation, confirmation and downgrade. Both affirmation and confirmation ratings have smallest standard deviations compared to standard deviation of downgrade which is slightly larger. Coefficients for the CPI are positive for these few ratings; new, upgrade, downgrade and withdrawal. This would have us suggest it is important for firms (especially for newly rated firms and potential firms to be upgraded) located in a country with high CPI value (represent low corruption) with greater transparency and information disclosure attracts more capital investments. It enhances corporate governance and increases firms' value for investors buying in a capital market. From a rating downgrade and withdrawal perspective, this is crucial since any less favorable change in the CPI value may impact ratings to deteriorate further so eventually investors will withdraw their investments. Political instability will increase if bribes and corruption are rampant affecting a firm's operations efficiency. Investors will be less willing to invest and thus in firms that are no longer rated (withdrawal) by the CRAs.

On the other hand, CPI's coefficients are negative for these ratings; affirmation, watch downgrade, watch upgrade and confirmation. An affirmation rating occurs when the rating committee resolved a formal Watchlist (downgrade or upgrade) assessment that the current ratings are retained. A confirmation happens when the rating is removed from the Watchlist. This suggests when there is no major news; the financials of the firms remain intact. Meanwhile, the CPI has not much influence on firms with ratings Watchlist. For firms that are placed under Watchlist pending final evaluation by the CRAs, their performance are not impacted yet.

The results discussed show different variables have different impacts on rating changes. The Ordered Probit helped to analyze the determinants at greater depth for each individual rating. Goh and Ederington (1993) report that rating changes cannot be treated as homogenous. There is no fixed set of factors held significant for all rating changes. The firm would have to improve its creditworthiness as quantified by the determinants to improve credit rating.

We observe there are more key determinants impacting watch downgrades and the downgrade ratings in comparisons to watch upgrade and upgrade ratings. This finding is consistent with existing reports in the literatures. Downgrades attract more attractions than upgrades. Any deterioration in a firm's financials will invite close attentions from investors. The variables are also significantly impacting new and affirmation ratings, which appear to signal important information to investors from this study. Affirmation and confirmation announcements are critical news and reassurances to market participants that the ratings remain unchanged, wherever information asymmetry is larger. These ratings serve as a certification signal of the issuer's credit quality. Investors probably are not disconcerted since there are no changes to the rating. As such, it warrants that investors pay more attention to these ratings; new, affirmation, confirmation and withdrawal. Knowing what and how much firm-specific factors impact these rating revisions will benefit them in their investment decision making. 
Table 4: Ordered Probit Results

\begin{tabular}{|c|c|c|c|c|c|c|c|c|}
\hline Panel A: & & & & & & & & \\
\hline Rating & z & 芯 & 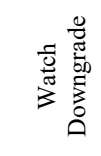 & 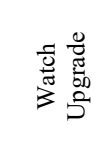 & 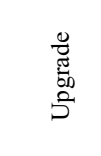 & 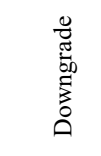 & 泀 & 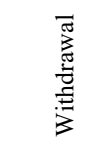 \\
\hline DGRADE & $\begin{array}{c}18.131 \\
(6.870) \\
* * *\end{array}$ & $\begin{array}{c}13.099 \\
(21.950) \\
* * *\end{array}$ & $\begin{array}{c}11.738 \\
(17.280) \\
* * *\end{array}$ & $\begin{array}{c}12.282 \\
(23.370) \\
* * *\end{array}$ & $\begin{array}{c}3.195 \\
(7.710) \\
* * *\end{array}$ & $\begin{array}{c}13.328 \\
(13.570) \\
* * *\end{array}$ & $\begin{array}{c}56.745 \\
(2.110) \\
* *\end{array}$ & $\begin{array}{c}12.217 \\
(14.260) \\
* * *\end{array}$ \\
\hline LNROCE & $\begin{array}{c}0.587 \\
(2.970) \\
* * *\end{array}$ & $\begin{array}{c}0.359 \\
(1.810) \\
*\end{array}$ & $\begin{array}{c}-0.212 \\
(-1.090)\end{array}$ & $\begin{array}{c}-0.062 \\
(-0.090)\end{array}$ & $\begin{array}{c}0.901 \\
(2.530) \\
* * *\end{array}$ & $\begin{array}{c}-0.099 \\
(-0.460)\end{array}$ & $\begin{array}{c}-0.772 \\
(-0.740)\end{array}$ & $\begin{array}{c}-0.242 \\
(-2.030) \\
* *\end{array}$ \\
\hline LNROA & $\begin{array}{c}0.186 \\
(1.650) \\
*\end{array}$ & $\begin{array}{c}-0.024 \\
(-0.230)\end{array}$ & $\begin{array}{c}-0.147 \\
(-1.110)\end{array}$ & $\begin{array}{c}0.715 \\
(1.980) \\
* *\end{array}$ & $\begin{array}{c}0.108 \\
(0.770)\end{array}$ & $\begin{array}{c}0.165 \\
(1.990) \\
* *\end{array}$ & $\begin{array}{c}4.115 \\
(2.290) \\
* *\end{array}$ & $\begin{array}{c}0.003 \\
(4.490) \\
* * *\end{array}$ \\
\hline $\begin{array}{l}\text { LNOPMAR } \\
\text { GIN }\end{array}$ & $\begin{array}{c}0.373 \\
(2.620) \\
* * *\end{array}$ & $\begin{array}{c}-0.124 \\
(-0.810)\end{array}$ & $\begin{array}{c}0.412 \\
(2.170) \\
* * *\end{array}$ & $\begin{array}{c}0.001 \\
(0.001)\end{array}$ & $\begin{array}{c}-0.172 \\
(-0.990)\end{array}$ & $\begin{array}{c}-0.160 \\
(-0.850)\end{array}$ & $\begin{array}{c}0.286 \\
(0.450)\end{array}$ & $\begin{array}{c}0.125 \\
(0.790)\end{array}$ \\
\hline $\begin{array}{l}\text { LNEBITDA } \\
\text { INT }\end{array}$ & $\begin{array}{c}-0.440 \\
(-2.590) \\
* * *\end{array}$ & $\begin{array}{c}-0.258 \\
(-1.800) \\
*\end{array}$ & $\begin{array}{c}-0.66 \\
(-3.230) \\
* * *\end{array}$ & $\begin{array}{c}-0.256 \\
(-0.990)\end{array}$ & $\begin{array}{c}-0.286 \\
(-1.350)\end{array}$ & $\begin{array}{l}-0.0426 \\
(-0.250)\end{array}$ & $\begin{array}{c}-5.001 \\
(-2.080) \\
* *\end{array}$ & $\begin{array}{c}0.173 \\
(0.610)\end{array}$ \\
\hline $\begin{array}{l}\text { LNLTDCA } \\
\mathrm{P}\end{array}$ & $\begin{array}{c}-0.138 \\
(-0.790)\end{array}$ & $\begin{array}{c}0.015 \\
(1.310)\end{array}$ & $\begin{array}{c}-0.110 \\
(-1.070)\end{array}$ & $\begin{array}{l}-0.376 \\
(-1.09)\end{array}$ & $\begin{array}{l}0.167 \# \\
(1.150)\end{array}$ & $\begin{array}{c}-0.056 \\
(-0.790)\end{array}$ & $\begin{array}{c}-3.001 \\
(-1.650) \\
*\end{array}$ & $\begin{array}{c}-0.138 \\
(-2.230) \\
* *\end{array}$ \\
\hline LNTDTA & $\begin{array}{c}0.026 \\
(0.180)\end{array}$ & $\begin{array}{c}0.560 \\
(1.965) \\
* *\end{array}$ & $\begin{array}{c}0.0864 \\
(1.690) \\
*\end{array}$ & $\begin{array}{c}-0.091 \\
(-0.510)\end{array}$ & $\begin{array}{c}0.040 \\
(0.150)\end{array}$ & $\begin{array}{c}-0.829 \\
(-1.740) \\
*\end{array}$ & $\begin{array}{c}0.961 \\
(0.400)\end{array}$ & $\begin{array}{c}0.267 \\
(2.410) \\
* *\end{array}$ \\
\hline LNCPI & $\begin{array}{c}0.114 \\
(0.640)\end{array}$ & $\begin{array}{c}-4.574 \\
(-1.930) \\
*\end{array}$ & $\begin{array}{c}-0.187 \\
(-0.080)\end{array}$ & $\begin{array}{c}-0.849 \\
(-1.260)\end{array}$ & $\begin{array}{c}0.073 \\
(0.480)\end{array}$ & $\begin{array}{c}0.618 \\
(2.550) \\
* * *\end{array}$ & $\begin{array}{c}-29.831 \\
(-2.560) \\
* *\end{array}$ & $\begin{array}{c}0.485 \\
(0.290)\end{array}$ \\
\hline \multicolumn{9}{|l|}{ Panel B: } \\
\hline Vif & 1.40 & 1.50 & 1.99 & 6.22 & 5.02 & 1.60 & 1.64 & 2.17 \\
\hline Wald chi2 & 1790 & 7341 & 2177 & 3483 & 145 & 2259 & 60 & 3392 \\
\hline Prob $>$ chi 2 & 0.000 & 0.000 & 0.000 & 0.000 & 0.000 & 0.000 & 0.000 & 0.000 \\
\hline Pseudo R2 & 0.5228 & 0.5437 & 0.4948 & 0.5033 & 0.4291 & 0.5295 & 0.795 & 0.578 \\
\hline
\end{tabular}

\section{Note:}

Robust coefficients and z-statistics reported (* denotes significant at 10\%; ** significant at 5\%; *** significant at $1 \%$ ).

All the variables are transformed to logarithm except for the re-investment (DGRADE).

DGRADE is a re-investment that takes value 0 for investment grade firms; and 1 for speculation grade firms.

LNROCE is return on capital (Earnings before interest and tax (EBIT)/total capital); LNROA is return on assets.

LNEBITDAInt is expressed in EBIT to total interest expense. (EBITDA is earnings before interest, tax, depreciation and amortization.)

LTDCAP is long-term debt to total capital; LNTDTA is long-term debt to total assets

LNOPMARGIN is operating margins; LNCPI refers to corruption perception index.

\# LNLTDCAP is omitted from the analysis of upgrade ratings due to high mulitcollinearity with total debt/total assets. Instead, we replaced with LNRETA (retained earnings/total assets) 


\section{CONCLUSION}

This paper differs from prior research on downgrades and upgrades whilst this research attempts to analyse the significant impacts on a full range of credit rating revisions (8 types). We contribute to rating literature by focusing on neglected rating movements by dissecting each credit rating revision at granular level using a powerful probit model. The results show that profitability, interest coverage ratio and leverage, all three, have significant impacts from the rating change decisions on the market prices. These are firm-specific variables that move with the price effect from rating changes. The methodology used has not been widely applied in prior studies, which make our findings novel and reliable. New, affirmation, confirmation and withdrawal ratings have been ignored as less important for not contributing any new information for too long, but this paper adds value by providing contrary evidence from these unstudied rating types.

From an economic and industry point of view, transparency on financial stability is the focus of quality. Countries with good sovereign credit ratings as the four developed nations we have chosen will attract more foreign direct investment resulting in local firms/industry enjoy low interest rates on debt securities. A low CPI (representing high corruption) is a burden on a nation's wealth and will discourage new investment, uncertainties and obstruct economic development. Private information released to the markets through credit rating changes announced to the market by the CRAs do not only impact rated firms but also influence other firms operating in the same industry. The latter assertion needs a separate in-depth study as well.

From an investor's point of view, identification of factors affecting each rating change is important as reported. Investors may be more watchful to recognize each credit rating change at the firm-specific level to ensure negative factors will not erode profits of their investment. The findings can be used as a reasonable proxy for firms to adopt strategies to capitalize on investment opportunities for fund providers. It aids investors to suffer less from underinvestment due to capital constraints by diverting them away from speculative-grade to investment-grade investments. It is also important for international investors in the context of optimal investment strategies and global portfolio diversification.

From a policy perspective, this distinction between investment and speculation ratings is vital because funding implications can be quite different. The capital losses due to a rating downgrade or rating withdrawal if invested in speculative-grade firms can be relatively huge and if the borrowers are government firms, the governments may force to change investment policies. The findings highlight the importance of credit ratings for policy makers in areas of financing, structuring and regulating markets, based on sound public finances are essential. Furthermore, financial stability depends on the solidity of fiscal conditions in each individual country.

Future more in-depth research on this topic will shed additional light by examining how corruption perception index affects credit rating changes over and above those factors in the firm, how sovereign level factors cascade to firm-level effects. It will be motivating enough to analyze developed versus emerging markets, which we have not done in this paper. A comparative study can be done using different countries to identify country-specific variables that may contribute to credit rating changes. Such extensions will help to build evidence about how the market 
intermediation process arising from credit ratings are affecting stock prices, which is value change at firm level.

\section{REFERENCES}

Adams, M., Burton, B., \& Hardwick, P. (2003). The determinants of credit ratings in the United Kingdom insurance industry. Journal of Business Finance \& Accounting, 30(3-4), 539572.

Agarwal, Y. (2013). Capital structure decisions: Evaluating risk and uncertainty. Singapore: John Wiley \& Sons.

Agnello, L., Castro, V., \& Sousa, R. M. (2018). The legacy and the tyranny of time: Exit and reentry of sovereigns to international capital markets. Journal of Money, Credit and Banking, 50(8), 1969-1994.

Akhigbe, A., Madura, J., \& Whyte, A. M. (1997). Intra-industry effects of bond rating adjustments. Journal of Financial Research, 20(4), 545-561.

Altman, E, (1968), Financial ratios. Discriminant analysis and the prediction of corporate bankruptcy. Journal of Finance, 28(5), 589-609.

Amato, J. D., \& Furfine, C. H. (2004). Are credit ratings procyclical?. Journal of Banking \& Finance, 28(11), 2641-2677.

Barron, M. J., Clare, A. D., \& Thomas, S. H. (1997). The effect of bond rating changes and new ratings on UK stock returns. Journal of Business Finance \& Accounting, 24(3), 497-509.

Becker, B., \& Milbourn, T. (2011). How did increased competition affect credit ratings? Journal of Financial Economics, 101(3), 493-514.

Black, B., \& Kim, W. (2012). The effect of board structure on firm value: A multiple identification strategies approach using Korean data. Journal of Financial Economics, 104(1), 203-226.

Blume, M. E., Lim, F., \& MacKinlay, A. C. (1998). The declining credit quality of US corporate debt: Myth or reality? The Journal of Finance, 53(4), 1389-1413.

Boot, A. W., Milbourn, T. T., \& Schmeits, A. (2006). Credit ratings as coordination mechanisms. Review of Financial Studies, 19(1), 81-118.

Brown, C., \& Davis, K. (2010). Australia's experience in the global financial crisis. Chapter 66, Lessons from the financial crisis: Causes, consequences, and our economic future, 537544.

Bouzouita, R., \& Young, A. J. (1998). A probit analysis of best ratings. Journal of Insurance Issues, 21(1), 23-34.

Cai, P., Gan, Q., \& Kim, S. J. (2018). Do sovereign credit ratings matter for foreign direct investments?. Journal of International Financial Markets, Institutions and Money, 55, 50-64.

Chan, L. K., Karceski, J., \& Lakonishok, J. (2007). Analysts' conflicts of interest and biases in earnings forecasts. Journal of Financial and Quantitative Analysis, 42(4), 893-913.

Christopher, A. (2012). The Credit Rating Controversy. Retrieved from https:// web.archive.org/web/20130727223220/http:/www.cfr.org/united-states/credit-ratingcontroversy/p22328

Corruption Perceptions Index. (2010). Transparency International. Retreived from https://www. transparency.org/en/cpi/2010 
Cunha, I., Ferreira, M. A., \& Silva, R. (2016). Can Credit Rating Agencies Affect Election Outcomes? Retrieved from https://www.ofce.sciences-po.fr/pdf-articles/actu /Ferreira.pdf

Dichev, I. D., \& Piotroski, J. D. (2001). The long-run stock returns following bond ratings changes. Journal of Finance, 56(1), 173-203.

Doumpos, M., Niklis, D., Zopounidis, C., \& Andriosopoulos, K. (2015). Combining accounting data and a structural model for predicting credit ratings: Empirical evidence from European listed firms. Journal of Banking \& Finance, 50, 599-607.

Elayan, F. A., Hsu, W. H., \& Meyer, T. O. (2003). The informational content of credit rating announcements for share prices in a small market. Journal of Economics and Finance, 27(3), 337-356.

Erdem, O., \& Varli, Y. (2014). Understanding the sovereign credit ratings of emerging markets. Emerging Markets Review, 20, $42-57$.

Fulghieri, P., Strobl, G., \& Xia, H. (2014). The economics of solicited and unsolicited credit ratings. Review of Financial Studies, 27(2), 484-518.

Goh, J. C., \& Ederington, L. H. (1993). Is a bond rating downgrade bad news, good news, or no news for stockholders? The Journal of Finance, 48(5), 2001-2008.

Graham, J. R., \& Harvey, C. R. (2001). The theory and practice of corporate finance: Evidence from the field. Journal of Financial Economics, 60(2), 187-243.

Gray, S., Mirkovic, A., \& Ragunathan, V. (2006). The determinants of credit ratings: Australian evidence. Australian Journal of Management, 31(2), 333-354.

Gujarati, D. N. (2003). Basic econometrics. New York: McGraw-Hill Education.

Harford, J., \& Uysal, V. B. (2014). Bond market access and investment. Journal of Financial Economics, 112(2), 147-163.

He, Y., Wang, J., \& Wei, K. J. (2011). Do bond rating changes affect the information asymmetry of stock trading?. Journal of Empirical Finance, 18(1), 103-116.

Holthausen, R. W., \& Leftwich, R. W. (1986). The effect of bond rating changes on common stock prices. Journal of Financial Economics, 17, 57-89.

Ismailescu, I.,\& Kazemi, H. (2010). The reaction of emerging market credit default swap spreads to sovereign credit rating changes. Journal of Banking \& Finance, 34(12), 2861-2873.

Jain, P. K., Kuvvet, E., \& Pagano, M. S. (2017). Corruption's impact on foreign portfolio investment. International Business Review, 26(1), 23-35.

Jiraporn, P., Jiraporn, N., Boeprasert, A., \& Chang, K. (2014). Does corporate social responsibility (CSR) improve credit ratings? Evidence from geographic identification. Financial Management, 43(3), 505-531.

Jorion, P., Liu, Z., \& Shi, C. (2005). Informational effects of regulation FD: evidence from rating agencies. Journal of Financial Economics, 76(2), 309-330.

Jorion, P., \& Zhang, G. (2007). Information effects of bond rating changes: The role of the rating prior to the announcement. Journal of Fixed Income, 16, 45-59.

Kaplan, R. S., \& Urwitz, G. (1979). Statistical models of bond ratings: A methodological inquiry. Journal of Business, 52(2), 231-261.

Karampatsas, N., Petmezas, D., \& Travlos, N. G. (2014). Credit ratings and the choice of payment method in mergers and acquisitions. Journal of Corporate Finance, 25, 474493.

KPMG. (2017). Review: IPOs and other Market Trends. Retrieved from https://assets.kpmg/ content/dam/kpmg/cn/pdf/en/2017/12/china-hk-ipo-2017-review.pdf

Lim, T. (2001). Rationality and analysts' forecast bias. The Journal of Finance, 56(1), 369-385. 
Livingston, M., \& Zhou, L. (2016). Information opacity and Fitch bond ratings. Journal of Financial Research, 39(4), 329-357.

Matolcsy, Z. P., \& Lianto, T. (1995). The incremental information content of bond rating revisions: The Australian evidence. Journal of Banking \& Finance, 19(5), 891-902.

May, A. D. (2010). The impact of bond rating changes on corporate bond prices: New evidence from the over-the-counter market. Journal of Banking \& Finance, 34(11), 2822-2836.

Mellios, C., \& Paget-Blanc, E. (2006). Which factors determine sovereign credit ratings?. The European Journal of Finance, 12(4), 361-377.

Modigliani, F., \& Miller, M. H. (1958). The cost of capital, corporation finance and the theory of investment. The American Economic Review, 48(3), 261-297.

Modina, M. (2015). Credit Rating and Bank-Firm Relationships: New Models to Better Evaluate SMEs. UK: Palgrave Macmillan.

Moody's. (2009). Moody's rating symbols and definitions. Retrieved from https://www.moodys. com/sites/products/AboutMoodysRatingsAttachments/MoodysRatingSymbolsandDefini tions.pdf

Myers, S. C., \& Majluf, N. S. (1984). Corporate financing and investment decisions when firms have information that investors do not have. Journal of Financial Economics, 13(2), 187-221.

Ng, A., \& Ariff, M. (2019). Does Credit Rating Revision Affect the Price of a Special Class of Common Stock?. Bursa Istanbul Review, 19(1), S44-S55.

Ozturk, H., Namli, E., \& Erdal, H. I. (2016). Reducing Overreliance on Sovereign Credit Ratings: Which Model Serves Better? Computational Economics, 48(1), 59-81.

Podobnik, B., Shao, J., Njavro, D., Ivanov, P. C., \& Stanley, H. E. (2008). Influence of corruption on economic growth rate and foreign investment. The European Physical Journal B, 63(4), 547-550.

Ryan, P. A., Villupuram, S. V., \& Zygo, J. G. (2017). The value of credit rating changes across economic cycles. Journal of Economics and Business, 92, 1-9.

Safari, M., \& Ariff, M. (2015). Sovereign credit rating change in emerging markets and its impact on their financial markets. International Journal of Bonds and Derivatives, 1(3), 203-216.

Shen, C. H., Huang, Y. L., \& Hasan, I. (2012). Asymmetric benchmarking in bank credit rating. Journal of International Financial Markets, Institutions and Money, 22(1), 171193.

Standard \& Poor's. (2006). Standard \& Poor's Corporate Ratings Criteria. Retrieved from http://sbufaculty.tcu.edu/mann/_Inv\%20II\%20F09/S\&P\%20Ratings\%20criteria\%20202006.pdf

Standard \& Poor's. (2017). Default, Transition, and Recovery: 2017 Annual Global Corporate Default Study and Rating Transitions. New York: NY. Retrieved from https://www. spglobal.com/en/research-insights/articles/default-transition-and-recovery-2017-annualglobal-corporate-default-study-and-rating-transitions

Sufi, A. (2009). The real effects of debt certification: Evidence from the introduction of bank loan ratings. The Review of Financial Studies, 22(4), 1659-1691.

Tang, T. T. (2009). Information asymmetry and firms' credit market access: Evidence from Moody's credit rating format refinement. Journal of Financial Economics, 93(2), 325351.

White, L. J. (2002). The credit rating industry: An industrial organization analysis. Ratings, Rating Agencies And The Global Financial System. In Levich, R. M., Majnoni, G., 
Reinhart, C. M. (Eds), Ratings, Rating Agencies and the Global Financial System (pp. 41-63). Boston: Springer.

Wilhelm, P. G. (2002). International validation of the corruption perceptions index: Implications for business ethics and entrepreneurship education. Journal of Business Ethics, 35(3), $177-189$.

Vives, X. (2006). Banking and regulation in emerging markets: The role of external discipline. The World Bank Research Observer, 21(2), 179-206. 


\section{APPENDIX 1}

\begin{tabular}{lcccccccc}
\hline \hline RATING & NEW & \multicolumn{7}{c}{ WATCH DOWNGRADE } \\
\hline Variable & Mean & S.Dev & Min & Max & Mean & S.Dev & Min & Max \\
DGRADE & 0.270 & 0.447 & 0.000 & 1.000 & 0.183 & 0.390 & 0.000 & 1.000 \\
LNCPI & 2.333 & 0.947 & 1.699 & 4.369 & 1.872 & 0.072 & 1.634 & 1.945 \\
LNEBITDAINT & 2.722 & 2.300 & -3.131 & 15.897 & 2.374 & 1.438 & -0.067 & 7.400 \\
LNLTDCAP & 2.965 & 1.429 & -2.040 & 4.310 & 2.642 & 2.576 & -9.579 & 4.354 \\
LNOPMARGIN & 2.314 & 1.108 & -1.194 & 4.043 & 2.498 & 1.103 & 0.630 & 5.790 \\
LNROA & -2.737 & 1.504 & -5.576 & 1.017 & -2.836 & 1.753 & -8.304 & 0.545 \\
LNROCE & -1.732 & 1.015 & -8.004 & 1.127 & -1.252 & 0.921 & -3.320 & 0.967 \\
LNTDTA & -1.613 & 1.741 & -13.720 & 0.107 & 1.325 & 0.390 & 0.036 & 2.466 \\
\hline \hline
\end{tabular}

\begin{tabular}{lcccccccc}
\hline \hline RATING & \multicolumn{1}{l}{ AFFIRMATION } & \multicolumn{7}{c}{ WATCH UPGRADE } \\
\hline Variable & Mean & S.Dev & Min & Max & Mean & S.Dev & Min & Max \\
DGRADE & 0.269 & 0.445 & 0.000 & 1.000 & 0.188 & 0.397 & 0.000 & 1.000 \\
LNCPI & 1.855 & 0.065 & 1.724 & 1.909 & 2.521 & 1.087 & 1.699 & 4.344 \\
LNEBITDAINT & 2.430 & 1.142 & -0.067 & 5.849 & 3.075 & 2.282 & 0.024 & 13.458 \\
LNLTDCAP & 9.803 & 13.724 & 0.000 & 71.010 & 2.377 & 0.931 & -0.010 & 4.227 \\
LNOPMARGIN & 2.233 & 0.990 & -0.020 & 4.007 & 1.466 & 2.458 & -3.173 & 4.286 \\
LNROA & -2.995 & 1.573 & -6.284 & 0.611 & -3.174 & 1.332 & -6.342 & 0.011 \\
LNROCE & -1.722 & 0.897 & -4.035 & 0.575 & -1.655 & 0.669 & -3.165 & 0.015 \\
LNTDTA & -1.254 & 0.611 & -2.932 & 0.694 & -2.003 & 2.607 & -15.091 & -0.454 \\
\hline \hline
\end{tabular}

\begin{tabular}{lcccccccc}
\hline \hline RATING & \multicolumn{2}{l}{ UPGRADE } & \multicolumn{7}{l}{ DOWNGRADE } \\
\hline Variable & Mean & S.Dev & Min & Max & Mean & S.Dev & Min & Max \\
DGRADE & 0.328 & 0.473 & 0.000 & 1.000 & 0.415 & 0.497 & 0.000 & 1.000 \\
LNCPI & 2.571 & 1.112 & 1.699 & 4.344 & 2.017 & 0.586 & 1.708 & 4.382 \\
LNEBITDAINT & 2.729 & 1.337 & -0.002 & 9.088 & 2.622 & 1.438 & -0.067 & 5.450 \\
LNLTDCAP & 2.793 & 2.611 & -14.881 & 4.686 & 2.719 & 2.762 & -9.210 & 4.350 \\
LNOPMARGIN & 2.480 & 0.888 & 0.003 & 4.227 & 2.085 & 0.941 & 0.000 & 3.834 \\
LNROA & -2.569 & 1.440 & -6.342 & 1.021 & -2.037 & 2.573 & -8.304 & 1.890 \\
LNROCE & -1.399 & 0.815 & -2.766 & 1.113 & -1.442 & 1.329 & -4.035 & 1.123 \\
LNTDTA & -1.585 & 1.918 & -15.060 & 0.018 & -1.223 & 0.713 & -5.044 & 1.057 \\
\hline \hline
\end{tabular}




\begin{tabular}{lcccccccc}
\hline \hline RATING & \multicolumn{1}{l}{ CONFIRMATION } & \multicolumn{7}{c}{ CONFIRMATION } \\
\hline Variable & Mean & S.Dev & Min & Max & Mean & S.Dev & Min & Max \\
DGRADE & 0.147 & 0.360 & 0.000 & 1.000 & 0.333 & 0.480 & 0.000 & 1.000 \\
LNCPI & 1.873 & 0.076 & 1.653 & 1.945 & 4.316 & 0.111 & 3.807 & 4.454 \\
LNEBITDAINT & 2.406 & 0.989 & -0.067 & 4.381 & -1.464 & 1.676 & -3.511 & 2.287 \\
LNLTDCAP & 2.881 & 2.467 & -9.210 & 4.228 & -1.965 & 3.066 & -6.718 & 1.360 \\
LNOPMARGIN & 2.372 & 1.115 & -1.966 & 3.917 & 3.227 & 1.652 & -0.462 & 5.113 \\
LNROA & -1.095 & 2.630 & -4.784 & 2.771 & 2.987 & 1.824 & 0.690 & 9.088 \\
LNROCE & -1.562 & 0.953 & -4.035 & 1.128 & 1.984 & 3.985 & -9.210 & 4.383 \\
LNTDTA & -1.232 & 0.635 & -3.219 & 0.709 & -2.480 & 4.475 & -24.271 & 1.057 \\
\hline \hline
\end{tabular}

